\title{
KINERJA KEUANGAN INDUSTRI KREATIF DI YOGYAKARTA PASCA ACFTA DAN AIFTA
}

\author{
Endra Murti Sagoro \\ Jurusan Pendidikan Akuntansi Universitas Negeri Yogyakarta \\ endra_ms@uny.ac.id
}

\begin{abstract}
Abstrak: Kinerja Keuangan Industri Kreatif di Yogyakarta Pasca ACFTA dan AIFTA. Penelitian ini bertujuan untuk menganalisis kinerja keuangan ditinjau dari tingkat penjualan dan tingkat laba. Secara khusus, penelitian ini bertujuan untuk mengetahui perbedaan tingkat penjualan dan tingkat laba sebelum dan setelah adanya ASEAN-China Free Trade Area (ACFTA) dan ASEAN-India Free Trade Area (AIFTA) pada UMKM industri kreatif yang ada di Yogyakarta.Penelitian ini merupakan penelitian kuantitatif. Populasi penelitian ini adalah UMKM anggota Dekranas Kota Yogyakarta. Sampel penelitian ini sebanyak 69 UMKM diambil dengan teknik random sampling. Data dalam penelitian ini dikumpulkan dengan dokumentasi. Teknik analisis data menggunakan analisis uji beda.Hasil penelitian ini menunjukkan bahwa: (1) Terdapat perbedaan tingkat penjualan UMKM industri kreatif di Yogyakarta sebelum dan setelah adanya ACFTA dan AIFTA yang ditunjukkan dengan nilai T hitung sebesar -3,230 dengan signifikansi 0,002; dan (2) Tidak terdapat perbedaan tingkat laba UMKM industri kreatif di Yogyakarta sebelum dan setelah adanya ACFTA dan AIFTA yang ditunjukkan dengan nilai T hitung sebesar -1,589 dengan signifikansi 0,117.
\end{abstract}

Kata kunci: ACFTA, AIFTA, Penjualan, Laba

\section{PENDAHULUAN}

Perjanjian Free Trade Area (FTA) yang dilakukan negara-negara di kawasan Asia Tenggara dengan negara di luar kawasan tersebut bertujuan untuk memperluas pemasaran dan peningkatan penjualan produk-produk yang dihasilkan oleh setiap negara yang turut serta dalam perjanjian tersebut. Indonesia merupakan salah satu negara di Asia Tenggara juga mengadakan perjanjian dengan beberapa negara dalam hal perdagangan bebas. Indonesia mengadakan perjanjian internasional dengan banyak negara yang berasal tidak hanya dari kawasan Asia. Pada Mei 2012 Indonesia telah terlibat dalam enam skema FTA, yaitu: ASEAN Free Trade Area (AFTA), ASEAN China Free Trade Area (ACFTA), ASEANKorea Free Trade Area (AKFTA), Indonesia-Japan Economic Partnership Agreement (IJEPA), ASEAN India Free Trade Area (AIFTA), dan ASEANAustralia-New Zealand (AANZ).Adanya FTA memberikan dampak, baik positif maupun negatif bagi negara-negara di kawasan ASEAN, termasuk Indonesia. Banyak perusahaan, khususnya Usaha Kecil Mikro Menengah (UMKM) Pemanufakturan di Indonesia yang akan menghadapi tantangan dengan adanya 


\section{JURNAL NOMINAL / VOLUME III NOMOR 1 / TAHUN 2014}

perjanjian perdagangan bebas khususnya ASEAN-China FTA (ACFTA), dengan ribuan pos tarif produk manufaktur menjadi nol persen per 1 Januari 2010. Dengan adanya pengurangan tarif, bahkan nol persen, produk-produk dari negara di kawasan ASEAN dan China akan lebih mudah masuk ke Indonesia dengan harga yang lebih murah. Di sisi lain, produkproduk dari Indonesia juga memiliki kesempatan yang sama untuk memasuki pasar di negara kawasan ASEAN dan China.

Terdapat pro dan kontra terhadap pemberlakuan ACFTA. Bagi pihak yang pro, menganggap bahwa pemberlakuan ACFTA sebagai kesempatan, tetapi bagi pihak yang kontra dipandang sebagai ancaman. Beberapa keuntungan dari ACFTA, antara lain Indonesia akan memiliki pemasukan tambahan dari PPN produk-produk baru yang masuk ke Indonesia. Semakin banyak produk China yang masuk ke Indonesia, makin banyak pula objek pajak sehingga dinilai berpotensi besar mendatangkan pendapatan pajak bagi pemerintah. Selain itu, adanya ACFTA akan memunculkan persaingan usaha yang diharapkan memicu persaingan harga yang sehat dan kompetitif sehingga pada akhirnya konsumen yang ada di Indonesia akan diuntungkan, karena barang yang dibutuhkan relatif terjangkau.Selain keuntungan, adanya ACFTA dianggap sebagai ancaman, khususnya bagi pihak yang kontra terhadap pemberlakuan ACFTA. ACFTA dianggap berpotensi membangkrutkan banyak perusahaan dalam negeri, khususnya UMKM. Pelaku UMKM dihadapkan dengan berbagai produk massal dari China dengan harga yang relatif lebih murah. Dengan adanya perjanjian ini, UMKM di Indonesia harus berani bersaing dengan produk-produk dari China dalam hal kualitas dan harga. Jika tidak mampu bersaing, UMKM yang ada di Indonesia khususnya UMKM Pemanufakturan akan berubah menjadi UMKM Dagang yang dirasa lebih menguntungkan. Namun, terdapat kemungkinan UMKM akan mengalami kebangkrutan. Banyaknya potensi kebangkrutan dari UMKM maka tenaga kerja lokal akan tercam diberhentikan sehingga akan memunculkan banyak pengangguran di Indonesia.

Salah satu UMKM Pemanufakturan di Indonesia adalah industri atau usaha kreatif. Industri kreatif ini memproduksi produkproduk kreatif yang akan dikonsumsi oleh konsumen lokal maupun asing. Pemasaran dari produk ini adalah pasar dalam negeri dan luar negeri. Tantangan bagi industri kreatif ini adalah produk-produk serupa yang berasal dari negara China. Kualitas yang dihasilkan minimal sepadan dengan harga yang dapat bersaing dengan pasar China. Namun, tidak semua industri kreatif memiliki pesaing dari China. Terdapat 


\section{JURNAL NOMINAL / VOLUME III NOMOR 1 / TAHUN 2014}

beberapa produk, khususnya produk yang berbahan baku dari sumber daya alam lokal hanya dihasilkan oleh beberapa daerah tertentu. Selain itu, produk yang dihasilkan berdasar pada budaya lokal tentunya pesaingnya sedikit atau bahkan tidak ada. Produk seperti ini tentunya dapat bersaing di dunia internasional, dengan catatan industri kreatif ini dikelola dengan baik. tidak adanya pengelolaan yang baik, akan menimbulkan ancaman bagi keberlangsungan industri kreatif tersebut, karena bukan tidak mungkin China dapat membuat produk kreatif yang sama bahkan dengan harga yang lebih murah.

Di sisi lain, pada tanggal yang sama (1 Januari 2010), Indonesia juga menghadapi ASEAN-India FTA (AIFTA). Melalui AIFTA, lebih dari 80 persen pos tarif akan diliberalisasi, termasuk produk khusus seperti minyak sawit mentah, kopi, teh, dan lada. Sekitar empat ribu pos tarif akan dieliminasi bertahap pada 2013 hingga 2016. Tarif untuk sensitif produk akan berkurang hingga lima persen pada 2016 dan sebanyak 489 pos tarif produk sangat sensitif akan menyusul. Produk-produk yang mengalami penurunan tarif antara lain produk kayu (plywood), alas kaki, produk kulit, dan produk bahan kimia. Menanggapi pemberlakuan efektif AIFTA, Menteri Perindustrian menilai perjanjian tersebut tidak akan berpotensi mengancam industri dalam negeri, seperti halnya pada AIFTA
(Vivanews, 4 Januari 2010). Berbeda dengan China yang unggul dengan produksi massalnya, India unggul di bidang teknologi dan informasi. Begitu pun kondisi industri di India, masih sama-sama mengalami kendala serupa di Indonesia, seperti di sektor perbankan. Dengan demikian, potensi ancaman bagi industri-industri yang ada di Indonesia dalam hal produk tidak terlalu signifikan. Namun, penguasaan teknologi dan informasi yang lebih baik dapat menjadi ancaman, khususnya dalam peningkatan kualitas produk sejenis dan jaringan pemasaran. Adanya AIFTA, dinilai belum akan mengancam industri kreatif yang ada di Indonesia, namun hal ini belum dapat dijamin 100\% dikarenakan perkembangan bisnis tentunya tidak lepas dari teknologi dan informasi. Jika sumber daya manusia yang mengelola industri kreatif di Indonesia tidak mampu menguasai teknologi dan mengakses informasi-informasi penting, maka ada kemungkinan pasar industri kreatif baik di Indonesia maupun ASEAN akan mulai dimasukki oleh India, khususnya produk yang berbahan kayu dan kulit.

Yogyakarta merupakan salah satu propinsi di Indonesia yang memiliki sumber daya alam luar biasa dan kebudayaan yang kuat. Selain itu, Yogyakarta juga memiliki daerah wisata yang cukup banyak dan sering dikunjungi oleh wisatawan baik yang berasal dari dalam negeri maupun luar negeri. Banyaknya potensi sumber daya 


\section{JURNAL NOMINAL / VOLUME III NOMOR 1 / TAHUN 2014}

alam dan daerah wisata memunculkan peluang-peluang usaha kreatif yang dapat dijadikan salah satu sumber pendapatan bagi masyarakat Yogyakarta. Beberapa usaha kreatif yang ada di Yogyakarta antara lain batik, perak, gerabah, kulit, kayu, maupun kerajinan-kerajinan yang berasal dari sumber daya lokal yang diolah agar memiliki nilai ekonomi yang tinggi. Sumber daya manusia yang berasal dari Yogyakarta memiliki tingkat kreativitas yang cukup tinggi. Hal ini terbukti dengan adanya produk-produk kreatif yang dihasilkan oleh masyarakat yang ada di Yogyakarta. Barang atau benda yang tadinya tidak diminati bahkan tidak dilirik oleh orang, diubah menjadi produk kreatif dan memiliki nilai ekonomi yang memiliki nilai jual. Kreativitas inilah pada akhirnya dapat menarik keinginan seseorang untuk membeli produk yang dihasilkan. Banyaknya produk kreatif dari Yogyakarta, dapat dijumpai di berbagai objek wisata yang ada di Yogyakarta. Selain itu, beberapa produk ini juga diekspor ke berbagai negara. Dari berbagai jenis industri kreatif tersebut, dengan adanya ACFTA dan AIFTA tidak jarang beberapa diantaranya mengalami penurunan penjualan produk kreatifnya. Namun, di sisi lain, ada pula industri kreatif yang tidak terpengaruh adanya perjanjian ACFTA dan AIFTA. Penurunan atau peningkatan penjualan di sektor industri kreatif sulit untuk diidentifikasi produk-produk apa saja yang terpengaruh oleh ACFTA dan produkproduk apa saja yang terpengaruh oleh AIFTA.

\section{Rumusan Masalah}

Rumusan masalah yang diajukan adalah sebagai berikut:

1. Bagaimana tingkat penjualan industri kreatif di Yogyakarta sebelum dan setelah adanya ACFTA dan AIFTA?

2. Bagaimana tingkat laba industri kreatif di Yogyakarta sebelum dan setelah adanya ACFTA dan AIFTA?

ASEAN-China Free Trade Area (ACFTA) ASEAN-China Free Trade Area (ACFTA) merupakan kesepakatan antara negara-negara anggota ASEAN dengan China untuk mewujudkan kawasan perdagangan bebas dengan menghilangkan atau mengurangi hambatan-hambatan perdagangan barang baik tarif ataupun non tarif, peningkatan akses pasar jasa, peraturan dan ketentuan investasi, sekaligus peningkatan aspek kerjasama ekonomi untuk mendorong hubungan perekonomian para pihak ACFTA dalam rangka meningkatkan kesejahteraan masyarakat ASEAN dan China.

Beberapa tujuan dari perjanjian ACFTA, antara lain adalah sebaagai berikut: (1) Memperkuat dan meningkatkan kerjasama ekonomi, perdagangan, dan 


\section{JURNAL NOMINAL / VOLUME III NOMOR 1 / TAHUN 2014}

investasi antara negara-negara anggota; (2) Meliberalisasi secara progresif dan meningkatkan perdagangan barang dan jasa serta menciptakan suatu sistem yang transparan dan untuk mempermudah investasi; (3) Menggali bidang-bidang kerjasama yang baru dan mengembangkan kebijaksanaan yang tepat dalam rangka kerjasama ekonomi antara negara-negara anggota; dan (4) Memfasilitasi integrasi ekonomi yang lebih efektif dari anggota ASEAN baru (Cambodia, Laos, Myanmar, dan Vietnam) dan menjembatani kesenjangan pembangunan ekonomi di antara negara-negara anggota.

Peluang adanya perjanjian ACFTA, antara lain adalah sebagai berikut: (1) Meningkatnya akses pasar ekspor ke China dengan tingkat tarif yang lebih rendah bagi produk-produk nasional;

Meningkatkanya kerjasama antara pelaku bisnis di kedua negara melalui pembentukan "Aliansi Strategis"; Meningkatnya akses pasar jasa di China bagi penyedia jasa nasional; (4) Meningkatnya arus investasi asing asal China ke Indonesia; dan (5) Terbukanya transfer teknologi antara pelaku bisnis di kedua negara.

Di sisi lain, manfaat adanya perjanjian ACFTA, antara lain adalah: (1) Terbukanya akses pasar produk pertanian (Chapter 01 s/d 08 menjadi 0\%) Indonesia ke China pada tahun 2004; (2) Terbukanya akses pasar ekspor Indonesia ke China pada tahun 2005 yang mendapatkan tambahan 40\% dari Normal Track ( \pm 1880 pos tarif), yang diturunkan tingkat tarifnya menjadi 05\%; (3) Terbukanya akses pasar ekspor Indonesia ke China pada tahun 2007 yang mendapatkan tambahan 20\% dari Normal Track ( \pm 940 pos tarif), yang diturunkan tingkat tarifnya menjadi 0-5\%, (4) Pada tahun 2010, Indonesia akan memperoleh tambahan akses pasar ekspor ke China sebagai akibat penghapusan seluruh pos tarif dalam Normal Track China; dan (5) Sampai dengan tahun 2010 Indonesia akan menghapuskan 93,39\% pos tarif (6.683 pos tarif dari total 7.156 pos tarif yang berada di Normal Track ), dan 100\% pada tahun 2012.

Selain manfaat yang ada dalam ACFTA, terdapat tantangan yang dihadapi dengan adanya perjanjian ACFTA, yaitu: (1) Indonesia harus dapat meningkatkan efisiensi dan efektifitas produksi sehingga dapat bersaing dengan produk-produk China; (2) Menciptakan iklim usaha yang kondusif dalam rangka meningkatkan daya saing, (3) Menerapkan ketentuan dan peraturan investasi yang transparan, efisien dan ramah dunia usaha; dan (4) Meningkatkan kemampuan dalam penguasaan teknologi informasi dan komunikasi termasuk promosi pemasaran dan lobby. 


\section{JURNAL NOMINAL / VOLUME III NOMOR 1 / TAHUN 2014}

ASEAN-India Free Trade Area (AIFTA)

India merupakan salah satu mitra dagang utama Indonesia dalam beberapa tahun terakhir. Perdagangan bilateral meningkat tajam, dari US\$ 2,8 miliar di tahun 2005 menjadi US\$ 4,9 miliar di tahun 2007, atau meningkat 28,8\%. Pengusaha India melakukan investasi di beberapa sektor penting di Indonesia, seperti tekstil, automotive, kimia dan petro-kimia, serta sektor jasa-jasa.Beberapa manfaat adanya perjanjian AIFTA bagi Indonesia antara lain adalah sebagai berikut: (1) Indonesia akan menikmati penghapusan bea masuk atas 70,14\% pos tarip India (3.666 tariff lines) pada tahun 2013 dan meningkat menjadi 79,35\% pos tarif (4.145 tariff lines) pada tahun 2016; (2) 94,75\% dari ekspor Indonesia ke India (US\$ 2.6 milyar) akan menikmati peningkatan akses pasar dalam 10 tahun ke depan, termasuk CPO dan RPO yang merupakan komoditas utama Indonesia ke pasar India; (3) India secara bertahap akan menurunkan bea masuk atas CPO dan RPO masing-masing dari $80 \%$ dan $90 \%$ menjadi $37,5 \%$ dan $45 \%$ selama periode 2009-2018. Hal ini merupakan keuntungan bagi Indonesia mengingat kedua produk andalan Indonesia tersebut akan memperoleh actual market access sampai dengan tahun 2018; (4) Komoditas utama Indonesia ke pasar India-batubara-juga akan menikmati bea masuk 0\%; (5) Sebaliknya komitmen Indonesia memberikan perlindungan cukup signifikan bagi industri nasional karena hanya $46,17 \%$ pos tarip Indonesia yang akan dihapuskan pada tahun 2016 (meskipun sesuai kesepakatan akan di-review bersama secara timbal-balik); (6) Jumlah penduduk India yang besar +1 milyar jiwa merupakan potensi pasar yang besar bagi produk Indonesia; (7) Penguasaan teknologi informasi dan bidang farmasi dari India dapat dimanfaatkan sebagai proses transfer teknologi bagi para pelaku bisnis; dan (8) Akan memacu pelaku bisnis pesaing Indonesia dalam memasuki pasar India.

Adanya AIFTA memberikan beberapa peluangproduk ekspor indonesia yang akan menikmati tarif 0\% di India, antara lain: (1) Produk Pertanian: binatang hidup, daging hewan, kacang mede, produk perikanan, susu, mentega, telur,produk hewani, pohon hidup dan bunga potong, sayuran, buahbuahan, kopi, teh, rempah, biji-bijian, getahgetahan, karet, lemak dan minyak nabati, produk daging dan ikan, gula dan kembang gula, coklat, dan sebagainya; dan (2) Produk Industri: produk agro dan kimia,produk farmasi, pupuk, bahan samak dan celup, produk fotografi, plastik dan produk plastik, karet dan produk karet, kulit dan produk kulit, kayu dan produk kayu, jerami dan produk anyaman, kertas dan produk kertas, tekstil dan produk tekstil, keramik dan kaca, besi dan logam, perkakas dan mesin, 


\section{JURNAL NOMINAL / VOLUME III NOMOR 1 / TAHUN 2014}

otomotif dan komponen, elektronik dan produk elektronik, furnitur, aneka karya seni dan berbagai barang buatan pabrik.

\section{Industri Kreatif}

Industri kreatif dapat diartikan sebagai kumpulan aktivitas ekonomi yang terkait dengan penciptaan atau penggunaan pengetahuan dan informasi. Industri kreatif juga dikenal dengan nama lain Industri Budaya (terutama di Eropa) atau juga Ekonomi Kreatif. Kementerian Perdagangan Indonesia menyatakan bahwa Industri kreatif adalah industri yang berasal dari pemanfaatan kreativitas, keterampilan serta bakat individu untuk menciptakan kesejahteraan serta lapangan pekerjaan dengan menghasilkan dan mengeksploitasi daya kreasi dan daya cipta individu tersebut.Menurut Howkins, Ekonomi Kreatif terdiri dari periklanan, arsitektur, seni, kerajinan. desain, fashion, film, musik, seni pertunjukkan, penerbitan, Penelitian dan Pengembangan (R\&D), perangkat lunak, mainan dan permainan, Televisi dan Radio, dan Permainan Video). Muncul pula definisi yang berbeda-beda mengenai sektor ini. Namun sejauh ini penjelasan Howkins masih belum diakui secara internasional.

Industri kreatif dipandang semakin penting dalam mendukung kesejahteraan dalam perekonomian, berbagai pihak berpendapat bahwa "kreativitas manusia adalah sumber daya ekonomi utama" dan bahwa "industri abad kedua puluh satu akan tergantung pada produksi pengetahuan melalui kreativitas dan inovasi.Berbagai pihak memberikan definisi yang berbedabeda mengenai kegiatan-kegiatan yang termasuk dalam industri kreatif. Bahkan penamaannya sendiri pun menjadi isu yang diperdebatkan dengan adanya perbedaan yang signifikan sekaligus tumpang tindih antara istilah industri kreatif, industri budaya, dan ekonomi kreatif.

Sub-sektor yang merupakan industri berbasis kreativitas di Indonesia berdasarkan pemetaan industri kreatif yang telah dilakukan oleh Departemen Perdagangan Republik Indonesia adalah periklanan, arsitektur, pasar barang seni, kerajinan, desain, fesyen, video, film dan fotografi, permainan interaktif, musik, seni pertunjukan, penerbitan dan percetakan, layanan komputer dan piranti lunak, televisi dan radio, riset dan pengembangan, serta kuliner.

\section{Kinerja Keuangan}

Kinerja keuangan perusahaan merupakan faktor internal atau bersifat mikro. Peristiwa yang terjadi di dalam perusahaan hanya akan mempengaruhi perusahaan atau industri tertentu, tidak berpengaruh pada perusahaan atau industri lain, sehingga peristiwa yang terjadi dapat dikendalikan perusahaan. Kinerja perusahaan biasanya diukur dari laporan 


\section{JURNAL NOMINAL / VOLUME III NOMOR 1 / TAHUN 2014}

keuangan yang dikeluarkan secara periodik, yang memberikan suatu gambaran tentang posisi keuangan perusahaan. Untuk menilai prestasi dan kondisi suatu perusahaan diperlukan ukuran-ukuran tertentu. Ukuran yang sering kali digunakan adalah rasio, yang menunjukkan hubungan antara dua data keuangan. Analisis rasio bertujuan untuk menilai keefektifan keputusan yang telah diambil perusahaan dalam rangka menjalankan aktivitas usahanya (Munawir, 2001). Analisis rasio ini sendiri memiliki berbagai keterbatasan, beberapa contohnya antara lain banyak perusahaan menggunakan teknik "window dressing" yaitu teknik untuk mempercantik laporan keuangan sehingga laporannya terlihat lebih baik, perbedaan praktek operasi dan akuntansi bisa menyebabkan adanya distorsi dalam perbandingan, kesulitan menentukan apakah suatu rasio "baik" atau "buruk" karena belum tentu rasio yang baik mencerminkan semua elemen penyusunnya adalah baik, dan biasanya suatu perusahaan bisa mempunyai sejumlah rasio yang kelihatan "baik" sedangkan rasio lainnya "jelek" sehingga sulit untuk mengatakan apakah secara keseluruhan perusahaan ini baik atau buruk (Helfert, 1996). Analisis rasio ini memang bermanfaat tetapi harus disesuaikan dengan kebutuhan penilaian perusahaan dan aspek apa yang akan dinilai. Kinerja keuangan dapat dilihat dari tingkat penjualan dan laba yang didapatkan oleh perusahaan.

Penjualan adalah suatu usaha yang terpadu untuk mengembangkan rencanarencana strategis yang diarahkan pada usaha pemuasan kebutuhan dan keinginan pembeli, guna mendapatkan penjualan yang menghasilkan laba (Marwan, 1991). Penjualan merupakan sumber hidup suatu perusahaan, karena dari penjualan dapat diperoleh laba serta suatu usaha memikat konsumen yang diusahakan untuk mengetahui daya tarik mereka sehingga dapat mengetahui hasil produk yang dihasilkan. Menurut Winardi (1982), penjualan adalah suatu transfer hak atas benda-benda. Dari penjelasan tersebut dalam memindahkan atau mentransfer barang dan jasa diperlukan orang-orang yang bekerja di bidang penjualan seperti pelaksana dagang, agen, wakil pelayanan dan wakil pemasaran.

Pada dasarnya laba usaha merupakan pendapatan perusahaan dikurangi biaya eksplisit atau biaya akuntansi perusahaan (Salvatore, 2005). Laba usaha berbeda dengan laba ekonomi, yaitu pendapatan perusahaan dikurangi dengan biaya eksplisit dan biaya implisit. Dalam akuntansi, laba kotor adalah keuntungan penjualan adalah perbedaan antara pendapatan dengan biaya untuk membuat suatu produk atau penyediaan jasa sebelum dikurangi biaya overhead, gaji, pajak dan pembayaran 


\section{JURNAL NOMINAL / VOLUME III NOMOR 1 / TAHUN 2014}

bunga. Perhatikan bahwa ini berbeda dari laba usaha (laba sebelum bunga dan pajak). Penjualan bersih didapatkan dengan cara

\section{Kerangka Pemikiran}

Kerangkan pemikiran dalam penelitian ini digambarkan sebagai berikut: mengurangi penjualan kotor dengan retur penjualan dan diskun penjualan.

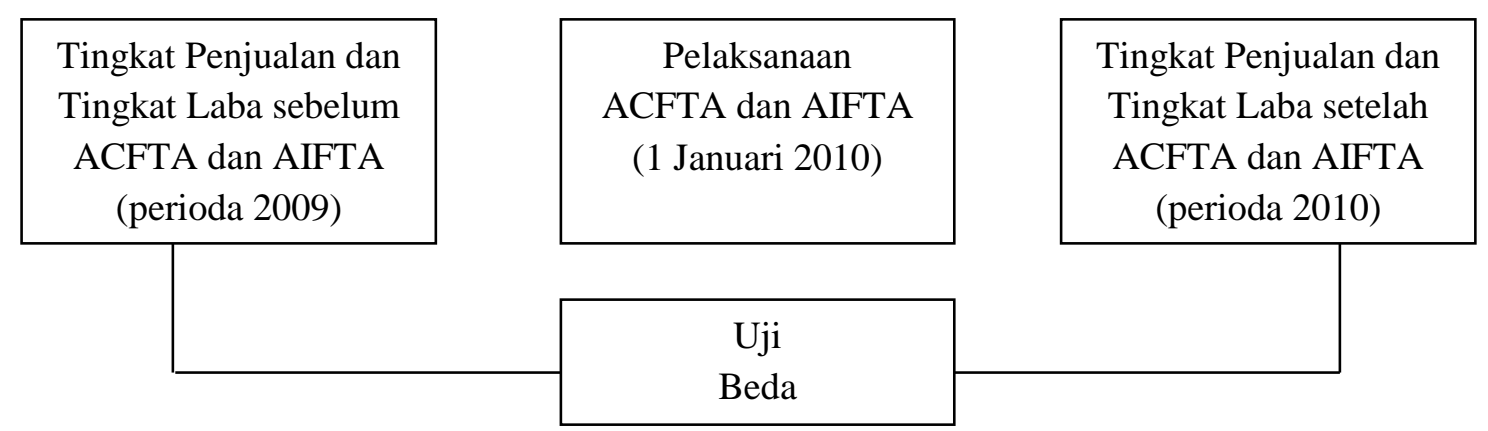

Gambar 1. Kerangka Pemikiran Penelitian

\section{Hipotesis Penelitian}

Hipotesis yang diajukan dalam penelitian ini adalah sebagai berikut:

H1: Terdapat perbedaan tingkat penjualan industri kreatif di Yogyakarta sebelum dan sesudah ACFTA dan AIFTA.

$\mathrm{H} 2$ : Terdapat perbedaan tingkat laba industri kreatif di Yogyakarta sebelum dan sesudah ACFTA dan AIFTA.

\section{METODA PENELITIAN}

Penelitian ini didesain sebagai penelitian kuantitatif dengan metoda survei terhadap pelaku UMKM khususnya industri kreatif di Yogyakarta. Adapun variabel yang akan diteliti adalah kinerja keuangan di
UMKM yang menjadi sampel ditinjau dari tingkat penjualan dan tingkat laba sebelum dan setelah pelaksanaan perjanjian ACFTA dan AIFTA.Populasi dalam penelitian ini adalah seluruh UMKM anggota Dekranas Kota Yogyakarta sebanyak 222 anggota yang berasal dari berbagai macam industri kreatif.Penghitungan sampel pada penelitian ini menggunakan penghitungan Slovin dengan menggunakan nilai kelonggaran ketidaktelitian $\left(\mathrm{e}^{2}\right)$ sebesar $10 \%$ diperoleh jumlah sampel sebesar 68,94 atau 69 UMKM. Data yang diperoleh dari penelitian ini berupa hasil dokumentasi atas tingkat penjualan dan tingkat laba. Analisis yang pertama adalah menganalisis tingkat penjualan dan tingkat laba untuk mengetahui dampak perjanjian ACFTA dan AIFTA. Penjualan dan laba sebelum dan 


\section{JURNAL NOMINAL / VOLUME III NOMOR 1 / TAHUN 2014}

setelah dilaksanakannya ACFTA dan AIFTA dihitung kenaikan atau penurunannya. Hasil perhitungan kenaikan atau penurunan penjualan dan laba digunakan sebagai data dalam pengujian statistik.

Pengujian statistik dilakukan dengan menguji tingkat penjualan sebelum dan sesudah ACFTA dan AIFTA, dan hasil pengujian ini diharapkan dapat mengetahui apakah ada perbedaan yang nyata pada kinerja keuangan yang dilihat melalui penjualan antara sebelum dan sesudah ACFTA dan AIFTA. Tahap-tahap pengujian menggunakan pengujian parsial untuk variabel penelitian dengan Paired Samples $T$ Test. Tingkat signifikansi atau nilai alfa pada penelitian ini ditetapkan adalah sebesar 0,05 atau 5\%. Pengujian hipotesis ini menggunakan uji Paired Samples T Test karena model uji beda tersebut populer digunakan untuk model penelitian pre-post atau sebelum-sesudah. Uji beda digunakan untuk mengevaluasi perlakuan (treatment) tertentu pada satu sampel yang sama pada dua periode pengamatan yang berbeda yaitu sebelum dan sesudah adanya treatment. Treatment tertentu pada penelitian ini adalah peristiwa perjanjian ACFTA dan AIFTA. Jika treatment tersebut tidak berpengaruh pada subjek, maka nilai ratarata pengukurannya adalah sama dengan atau dianggap nol dan hipotesis nol (Ho)nya tidak didukung, yang berarti hipotesis alternatifnya didukung. Paired Samples T Test atau uji $\mathrm{T}$ sampel berpasangan merupakan uji parametrik yang digunakan untuk menguji hipotesis sama atau tidak berbeda (Ho) di antara dua variabel. Data berasal dari dua pengukuran atau dua periode pengamatan yang berbeda yang diambil dari subjek yang dipasangkan.

\section{HASIL PENELITIAN DAN PEMBAHASAN}

\section{Hasil Penelitian}

Penelitian dilakukan di 69 UMKM yang telah terpilih menjadi responden. Data didapatkan melalui angket dan dokumentasi. Angket digunakan untuk memperoleh informasi mengenai gambaran umum UMKM yang menjadi subjek penelitian, seperti jenis usaha, pengetahuan tentang ACFTA dan AIFTA, persaingan dengan China dan India, transaksi dengan China dan India, pengaruh ACFTA dan AIFTA, serta peningkatan atau penurunan penjualan dan laba setelah adanya ACFTA dan AIFTA. Dokumentasi digunakan untuk mengungkapkan penjualan dan laba sebelum dan sesudah adanya ACFTA dan AIFTA. Berdasarkan angket yang telah terisi, informasi yang didapatkan tersaji dalam tabel 1 sampai dengan tabel 4 berikut. 
Tabel 1. Jenis Usaha UMKM

\begin{tabular}{lcc}
\hline Klasifikasi Jenis Usaha UMKM & Jumlah & Persentase (\%) \\
\hline Kerajinan Perak & 4 & 5,80 \\
Kerajinan Batik & 8 & 11,59 \\
Kerajinan Gerabah & 5 & 7,25 \\
Kerajinan Bambu & 2 & 2,90 \\
Kerajinan Kulit & 4 & 5,80 \\
Kerajinan Serat Alam & 1 & 1,45 \\
Kreasi Asesoris & 19 & 27,54 \\
Kreasi Souvenir & 26 & 37,68 \\
Total & 69 & 100,00 \\
\hline
\end{tabular}

Tabel 2. UMKM, ACFTA, dan AIFTA

\begin{tabular}{|c|c|c|c|c|c|c|}
\hline & $\begin{array}{l}\text { Tahu } \\
\text { ACFTA }\end{array}$ & $\begin{array}{l}\text { Tahu } \\
\text { AIFTA }\end{array}$ & $\begin{array}{l}\text { Bersaing } \\
\text { dengan } \\
\text { produk China }\end{array}$ & $\begin{array}{l}\text { Bersaing } \\
\text { dengan } \\
\text { produk India }\end{array}$ & $\begin{array}{l}\text { Transaksi } \\
\text { dengan } \\
\text { China }\end{array}$ & $\begin{array}{l}\text { Transaksi } \\
\text { dengan } \\
\text { India }\end{array}$ \\
\hline Jumlah & 69 & 44 & 46 & 16 & 14 & 11 \\
\hline Persentase & 100,00 & 63,77 & 66,67 & 23,19 & 20,29 & 15,94 \\
\hline
\end{tabular}

Tabel 3. Pengaruh ACFTA dan AIFTA bagi UMKM

\begin{tabular}{lrrrrrr}
\hline & $\begin{array}{l}\text { ACFTA } \\
\text { (positif) }\end{array}$ & $\begin{array}{c}\text { ACFTA } \\
\text { (negatif) }\end{array}$ & $\begin{array}{c}\text { ACFTA } \\
\text { (netral) }\end{array}$ & $\begin{array}{c}\text { AIFTA } \\
\text { (positif) }\end{array}$ & $\begin{array}{c}\text { AIFTA } \\
\text { (negatif) }\end{array}$ & $\begin{array}{c}\text { AIFTA } \\
\text { (netral) }\end{array}$ \\
\hline Jumlah & 4 & 25 & 40 & 5 & 10 & 54 \\
Persentase & 5,80 & 36,23 & 57,97 & 7,25 & 14,49 & 78,26 \\
\hline
\end{tabular}

Tabel 4. Kenaikan atau Penurunan Penjualan dan Laba

\begin{tabular}{lcccc}
\hline \multicolumn{1}{c}{ Keterangan } & $\begin{array}{c}\text { Jumlah } \\
\text { UMKM }\end{array}$ & $\begin{array}{c}\text { Minimal } \\
(\%)\end{array}$ & $\begin{array}{c}\text { Maksimal } \\
(\%)\end{array}$ & $\begin{array}{c}\text { Rata-rata } \\
(\%)\end{array}$ \\
\hline Peningkatan penjualan & 53 & 3,20 & 60,00 & 21,17 \\
Penurunan penjualan & 16 & 5,00 & 41,67 & 19,39 \\
Peningkatan laba & 47 & 5,00 & 66,67 & 20,30 \\
Penurunan laba & 22 & 2,08 & 42,86 & 20,42 \\
\hline
\end{tabular}




\section{Analisis Data}

Pengujian yang dilakukan adalah dengan pengujian statistik parametrik dengan menggunakan Paired Samples T Test. Uji ini digunakan untuk mengetahui apakah ada perbedaan rata-rata dua sample yang berhubungan. Dengan sampel tetap yang sama hanya perbedaanya adalah kasus sebelum dan sesudah yaitu sebelum dan sesudah adanya ACFTA dan AIFTA (per 1 Januari 2010) khususnya penjualan dan laba yang didapatkan UMKM untuk perioda 2009 dan 2010.
Hipotesis satu dan dua untuk menguji tingkat penjualan dan tingkat laba. Digunakan uji Paired Samples T Test untuk menguji apakah ada perbedaan tingkat penjualan dan tingkat laba yaitu yang mengarah pada peningkatan atau penurunan sesudah dilaksanakannya ACFTA dan AIFTA. Hasil analisis data untuk uji Paired Samples T Test dapat dilihat pada tabel 5 berikut.

Tabel 5. Hasil Uji Paired Samples T Test pada Penjualan dan Laba

\begin{tabular}{lrrrrc}
\hline \multicolumn{1}{c}{ Kinerja } & \multicolumn{2}{c}{ Paired Samples T Test } & \multicolumn{2}{c}{ Kesimpulan } \\
& Mean & T hitung & Sig (2-tailed) & \multicolumn{1}{c}{ sd } & \\
\hline Penjualan & $-2,990$ & $-3,230$ & 0,002 & 7,689 & Didukung \\
Laba & $-4814492,754$ & $-1,589$ & 0,117 & 2,517 & Tidak didukung \\
Peningkatan & $-5,257$ & $-5,720$ & 0,000 & 6,690 & Didukung \\
Penjualan & & & & & \\
Penurunan & 4,519 & 3,074 & 0,008 & 5,880 & Didukung \\
Penjualan & $-1,430$ & $-5,385$ & 0,000 & 1,821 & Didukung \\
Peningkatan & & & & & \\
Laba & 1,546 & 2,754 & 0,012 & 2,632 & Didukung \\
Penurunan & & & & \\
Laba & & & & & \\
\hline
\end{tabular}

Berdasarkan tabel 5, dapat diketahui bahwa nilai $\mathrm{T}$ hitung untuk penjualan sebesar -3,230 dengan signifikansi sebesar 0,002. Nilai $\mathrm{T}$ hitung negatif berarti penjualan sebelum adanya ACFTA dan AIFTA lebih kecil dibandingkan dengan penjualan sesudah adanya ACFTA dan AIFTA. Dengan kata lain UMKM mengalami peningkatan penjualan apabila 


\section{JURNAL NOMINAL / VOLUME III NOMOR 1 / TAHUN 2014}

dibandingkan dengan sebelum adanya ACFTA dan AIFTA. Sedangkan nilai signifikansi sebesar 0,000. Oleh karena signifikansi sebesar $0,000<0,05$, maka kesimpulan yang dapat diambil adalah terdapat perbedaan signifikan antara tingkat penjualan sebelum dan sesudah ACFTA dan AIFTA. Perbedaan tingkat penjualan dalam hal ini adalah tingkat penjualan UMKM setelah adanya ACFTA dan AIFTA, yaitu tingkat penjualan selama perioda 2010 lebih besar dibandingkan tingkat penjualan pada perioda 2009. Dengan demikian, hipotesis pertama yang menyatakan bahwa terdapat perbedaan tingkat penjualan industri kreatif di Yogyakarta sebelum dan sesudah ACFTA dan AIFTA dapat didukung.

Pada data tentang tingkat laba diperoleh informasi bahwa nilai $\mathrm{T}$ hitung sebesar 1,589 dengan signifikansi 0,117 . Nilai $T$ hitung negatif berarti laba sebelum adanya ACFTA dan AIFTA lebih kecil dibandingkan dengan laba sesudah adanya ACFTA dan AIFTA. Dengan kata lain UMKM mengalami peningkatan laba apabila dibandingkan dengan sebelum adanya ACFTA dan AIFTA. Sedangkan nilai signifikansi sebesar 0,117 . Oleh karena signifikansi sebesar $0,117>0,05$, maka kesimpulan yang dapat diambil adalah tidak terdapat perbedaan signifikan antara tingkat laba sebelum dan sesudah ACFTA dan AIFTA. Hal ini berarti bahwa sebenarnya tingkat laba yang diperoleh UMKM pada perioda 2009 dan prioda 2010 tidak berbeda secara signifikan. Berdasarkan hasil analisis tersebut, dapat diambil kesimpulan bahwa hipotesis kedua yang menyatakan terdapat perbedaan tingkat laba industri kreatif di Yogyakarta sebelum dan sesudah ACFTA dan AIFTA tidak didukung.

Dari tabel 5, dapat dilihat juga hasil pengujian Paired Samples $T$ Test pada masing-masing penjualan dan laba yang mengalami peningkatan atau penurunan secara terpisah. Pengujian ini digunakan untuk membuktikan ada tidaknya perbedaan tingkat penjualan dan tingkat laba sebelum dan setelah adanya ACFTA dan AIFTA pada UMKM yang mengalami peningkatan atau penurunan penjualan saja dan UMKM yang mengalami peningkatan atau penurunan laba saja. Berdasarkan pengujian tersebut dapat diketahui bahwa pada UMKM yang mengalami peningkatan penjualan diperoleh nilai $\mathrm{T}$ hitung sebesar 5,720 dengan signifikansi 0,000 . Nilai $T$ hitung negatif berarti penjualan sebelum adanya ACFTA dan AIFTA lebih kecil dibandingkan dengan penjualan sesudah adanya ACFTA dan AIFTA. Sedangkan nilai signifikansi sebesar 0,000 . Oleh karena signifikansi sebesar $0,000<0,05$, maka kesimpulan yang dapat diambil adalah terdapat perbedaan signifikan antara tingkat penjualan sebelum dan sesudah ACFTA dan AIFTA pada UMKM yang mengalami peningkatan penjualan. 


\section{JURNAL NOMINAL / VOLUME III NOMOR 1 / TAHUN 2014}

Pada UMKM yang mengalami penurunan penjualan diperoleh nilai $\mathrm{T}$ hitung sebesar 3,074 dengan signifikansi 0,008. Nilai $\mathrm{T}$ hitung positif berarti penjualan sebelum adanya ACFTA dan AIFTA lebih besar dibandingkan dengan penjualan sesudah adanya ACFTA dan AIFTA. Sedangkan nilai signifikansi sebesar 0,008. Oleh karena signifikansi sebesar $0,008<0,05$, maka kesimpulan yang dapat diambil adalah terdapat perbedaan signifikan antara tingkat penjualan sebelum dan sesudah ACFTA dan AIFTA pada UMKM yang mengalami penurunan penjualan.

Pada UMKM yang mengalami peningkatan laba diperoleh nilai $\mathrm{T}$ hitung sebesar -5,385 dengan signifikansi 0,000. Nilai $\mathrm{T}$ hitung negatif berarti laba sebelum adanya ACFTA dan AIFTA lebih kecil dibandingkan dengan laba sesudah adanya ACFTA dan AIFTA. Sedangkan nilai signifikansi sebesar 0,000. Oleh karena signifikansi sebesar $0,000<0,05$, maka kesimpulan yang dapat diambil adalah terdapat perbedaan signifikan antara tingkat laba sebelum dan sesudah ACFTA dan AIFTA pada UMKM yang mengalami peningkatan laba.

Pada UMKM yang mengalami penurunan laba diperoleh nilai $\mathrm{T}$ hitung sebesar 1,546 dengan signifikansi 0,012. Nilai $\mathrm{T}$ hitung positif berarti laba sebelum adanya ACFTA dan AIFTA lebih besar dibandingkan dengan laba sesudah adanya ACFTA dan AIFTA. Sedangkan nilai signifikansi sebesar 0,012. Oleh karena signifikansi sebesar $0,012<0,05$, maka kesimpulan yang dapat diambil adalah terdapat perbedaan signifikan antara tingkat laba sebelum dan sesudah ACFTA dan AIFTA pada UMKM yang mengalami penurunan laba.

\section{Pembahasan}

Berdasarkan hasil penelitian yang telah dilakukan pada UMKM yang menjadi subjek penelitian diperoleh data bahwa sebagian besar UMKM khususnya industri kreatif yang ada di Yogyakarta bergerak di bidang kreasi souvenir. Hal ini tentunya tidak terlepas dari peluang yang ada di Yogyakarta yang merupakan salah satu kota tujuan wisata sehingga banyak pelaku UMKM yang memproduksi beraneka ragam souvenir yang bisa dijadikan oleh-oleh bagi para wisatawan. UMKM industri kreatif yang ada di Yogyakarta sebagian mengetahui adanya ACFTA dan AIFTA yang telah disepakati pada tanggal 1 Januari 2010. Terdapat berbagai tanggapan mengenai adanya ACFTA dan AIFTA. Beberapa UMKM menyatakan bahwa mereka harus bersaing dengan produk yang berasal dari China dan India, namun sebagian UMKM juga menyatakan bahwa mereka tidak bersaing dengan produk dari China dan India. UMKM yang menyatakan 


\section{JURNAL NOMINAL / VOLUME III NOMOR 1 / TAHUN 2014}

tidak bersaing dengan China dan India antara lain adalah UMKM yang memproduksi barang dengan bahan baku yang hanya ada di Yogyakarta atau memproduksi barang dengan ciri khas Yogyakarta.

Beberapa UMKM industri kreatif yang ada di Yogyakarta juga telah melakukan transaksi dengan China dan India. Beberapa UMKM menyatakan bahwa adanya ACFTA dan AIFTA memberikan dampak bagi usaha yang mereka jalankan, namun sebagian besar UMKM industri kreatif, yaitu sebesar 57,97\% menyatakan bahwa ACFTA tidak berdampak bagi UMKM dan sebesar $78,26 \%$ menyatakan bahwa AIFTA tidak berdampak bagi usaha yang mereka jalankan.

Di sisi lain, adanya ACFTA dan AIFTA sebenarnya membuka peluang bagi UMKM untuk meningkatkan potensi penjualan dan potensi pemasaran bagi UMKM industri kreatif. Banyaknya wisatawan asing di Yogyakarta yang berasal dari berbagai negara memberikan peluang bagi UMKM untuk melakukan ekspor pasif. Adanya ekspor pasif dari UMKM ke luar negeri melalui wisatawan dapat membuka peluang bagi UMKM untuk memasuki bisnis internasional. Adanya ACFTA dan AIFTA akan mempermudah UMKM dalam hal finansial karena beberapa tarif akan menjadi nol sehingga biaya yang dikeluarkan untuk melakukan ekspor aktif menjadi lebih ringan. Berdasarkan hasil penelitian, setelah adanya ACFTA dan AIFTA sebagian besar UMKM yaitu sebesar $76,81 \%$ mengalami peningkatan penjualan dengan rata-rata peningkatan sebesar $21,17 \%$ daripada sebelum adanya ACFTA dan AIFTA. Selain itu, sebagian besar UMKM yaitu sebesar $68,12 \%$ juga mengalami peningkatan laba setelah adanya ACFTA dan AIFTA dengan rata-rata peningkatan sebesar $20,30 \%$. Banyaknya UMKM yang mengalami peningkatan baik penjualan maupun laba menunjukkan bahwa terdapat dua hal yang dapat disimpulkan, yaitu UMKM merespon positif ACFTA dan AIFTA atau UMKM sama sekali tidak merespon adanya ACFTA dan AIFTA.

Berdasarkan analisis data yang dilakukan pada tingkat penjualan dan tingkat laba, baik secara terpisah pada penjualan yang mengalami peningkatan maupun penjualan yang mengalami penurunan, serta penjualan secara keseluruhan atau laba yang mengalami peningkatan maupun laba yang mengalami penurunan, serta laba secara keseluruhan menunjukkan bahwa dengan adanya ACFTA dan AIFTA menimbulkan perbedaan secara signifikan pada tingkat penjualan, baik secara keseluruhan atau terpisah. Pada analisis laba secara keseluruhan, adanya ACFTA dan AIFTA tidak menimbulkan perbedaan yang signifikan, namun secara terpisah ACFTA 


\section{JURNAL NOMINAL / VOLUME III NOMOR 1 / TAHUN 2014}

dan AIFTA menimbulkan perbedaan yang signifikan.

Penjualan yang mengalami penurunan setelah adanya ACFTA dan AIFTA dinilai masih wajar, hal ini tentunya dikarenakan persaingan dengan produk-produk dari China dan India dengan harga yang relatif lebih murah. Namun, UMKM yang mengalami penurunan jumlahnya lebih sedikit jika dibandingkan dengan UMKM yang mengalami peningkatan laba setelah adanya ACFTA dan AIFTA. Hal ini memberikan gambaran bahwa usaha kreatif tetap mampu meningkatkan penjualannya setelah adanya ACFTA dan AIFTA.

Berdasarkan hasil analisis data, laba secara keseluruhan tidak terdapat perbedaan antara sebelum dan sesudah adanya ACFTA dan AIFTA. Peningkatan dan penurunan laba usaha tidak hanya dipengaruhi penjualan saja. Peningkatan penjualan tidak selalu diiringi dengan peningkatan laba. Beberapa hal yang mempengaruhi laba selain tingkat penjualan adalah biaya-biaya yang dikeluarkan oleh UMKM untuk memperoleh pendapatan dari penjualan yang dilakukan. Peningkatan penjualan yang tidak diiringi dengan peningkatan laba atau bahkan penurunan, menunjukkan UMKM mengalami masalah dalam hal efisiensi.

Adanya ACFTA dan AIFTA pada dasarnya sedikit banyak memberikan perbedaan bagi tingkat penjualan dan tingkat laba yang dihasilkan oleh UMKM. Namun, di sisi lain, perbedaan ini juga tergantung pada UMKM itu sendiri. Khususnya bagi UMKM industri kreatif, produk-produk mereka dapat bersaing dengan produk dari China dan India. Hal ini juga terlihat dari hasil angket yang didapatkan bahwa sebagian besar pemilik UMKM industri kreatif memberikan pernyataan bahwa adanya ACFTA dan AIFTA tidak mempengaruhi UMKM yang mereka jalankan.

Perbedaan antara hasil analisis terhadap tingkat penjualan dan tingkat laba dengan pernyataan dari pemilik UMKM tentunya menimbulkan tanda tanya, apakah perbedaan tingkat penjualan dan tingkat laba yang didapatkan UMKM terjadi setelah adanya ACFTA dan AIFTA. Terlebih bagi UMKM industri kreatif yang memiliki ciri khusus yang dapat membedakan UMKM tersebut dengan para pelaku bisnis yang lain di luar negeri, tentunya adanya ACFTA dan AIFTA dapat membuka peluang mereka untuk memasuki pasar internasional. Jika UMKM mampu memanfaatkan adanya ACFTA dan AIFTA, sangat dimungkinkan tingkat penjualan dan tingkat laba UMKM dapat meningkat.

\section{SIMPULAN DAN SARAN}

\section{Kesimpulan}

Berdasarkan hasil penelitian dan analisis data mengenai tingkat penjualan 


\section{JURNAL NOMINAL / VOLUME III NOMOR 1 / TAHUN 2014}

dan tingkat laba sebelum dan setelah adanya ACFTA dan AIFTA, maka dapat diambil kesimpulan:

1. Terdapat perbedaan tingkat penjualan UMKM industri kreatif di Yogyakarta sebelum dan setelah adanya ACFTA dan AIFTA. Hal ini ditunjukkan dengan nilai $\mathrm{T}$ hitung sebesar $-3,230$ dengan signifikansi 0,002.

2. Tidak terdapat perbedaan tingkat laba UMKM industri kreatif di Yogyakarta sebelum dan setelah adanya ACFTA dan AIFTA. Hal ini ditunjukkan dengan nilai $\mathrm{T}$ hitung sebesar $-1,589$ dengan signifikansi 0,117.

\section{Saran}

Berdasarkan hasil penelitian ini, beberapa saran yang dapat diajukan antara lain adalah:

1. Sebaiknya dilakukan penelitian lebih lanjut khususnya bagi UMKM yang telah melakukan ekspor aktif ke kawasan ASEAN, China, dan India.

2. Sebaiknya UMKM industri kreatif memanfaatkan adanya ACFTA dan AIFTA untuk meningkatkan penjualan dan memperluas pangsa pasar khususnya di tingkat internasional karena banyak UMKM yang menyatakan produk industri kreatif tidak bersaing dengan produk dari China dan India.

\section{DAFTAR PUSTAKA}

Dewitari, Sai’o. R., R. A., Erika, Andriyanto.T. 2009.“ASEAN-China Free Trade Area (ACFTA) Agreement as an International Regime: The Impact Analysis on ASEAN" .Artikel tidak dipublikasikan. Department Of International Relations Faculty osf Political and Social Science University of Indonesia.

Direktorat Kerjasama Regional, Ditjen Kerjasama Perdagangan Internasional. 2010. ASEAN-China Free Trade Area.

Direktorat Kerjasama Regional, Ditjen Kerjasama Perdagangan Internasional. 2010. ASEAN-India Free Trade Area.

Helfert, Erich A. 1996. Financial Management. Jakarta: Erlangga.

Indriantoro, N dan Supomo, B. 1999. Metodologi Penelitian Bisnis, untuk Akuntansidan Manajemen.Edisi

Pertama. Yogyakarta: BPFE.

Kountur, Ronny. 2004. Metode Penelitian untuk Penulisan Skripsi. Jakarta: PPM.

Laksana, 2002, "AFTA: Globalisasi Ekonomi Regional dan Implikasinya", JPI,Vol.1,pp.10-18.

Mulyadi.1997. Akuntansi Manajemen: Konsep, Manfaat dan Rekayasa. Cetakan II. Yogyakarta: Sekolah Tinggi Ilmu Ekonomi YKPN.

Munawir. 2001. Analisa Laporan Keuangan. Edisi Keempat. Yogyakarta: Liberty. 
Santoso. Singgih.2000. Buku Latihan SPSS:

Statistik Parametrik. Jakarta: Elex

Media Komputindo.

Salvatore, Dominick. 2005. Ekonomi Manajerial dalam Perekonomian Global. Jakarta: Salemba Empat.

Sekaran.Uma.2006. Research MethodsFor Business (Metodologi Penelitian untuk Bisnis). Cetakan IV.Jakarta: Salemba Empat.

Suharsimi Arikunto. 2006. Prosedur Penelitian, Suatu Pendekatan Praktek, EdisiRevisi IVJakarta: Rhineka Cipta.

Vivanews. 2010. Indonesia Juga Hadapi FTA Asean-India. http://bisnis.news. viva.co.id/news/read/118420indonesia_juga_hadapi_fta_asean_india. (diakses pada 14 Maret 2013).

Wikipedia. 2010. Industri Kreatif. http://id.wikipedia.org/wiki/Industri_kre atif. (diakses pada 16 Maret 2013). 